\title{
Far from heaven, Grounded on Earth: Environmental (In)justice in South Korea
}

\author{
Lejos del cielo, anclado en la tierra: (in)justicia ambiental en Corea del Sur
}

Antonio OrTega SAntos

Universidad de Granada aortegas@ugr.es

SuSANA Herráiz MARTin

Universidad de Granada susanka@correo.ugr.es

ENRIQUE MORA ROÁS

Universidad de Granada enrmorroa@correo.ugr.es

\section{Resumen}

Durante años hemos estado desarrollando varios proyectos de investigación en el campo de la historia ambiental, prestando especial atención a los estudios sobre conflictos ambientales. Esta mirada hacia la resistencia en defensa de los territorios, ha sido asumida por ONG, investigadores, académicos pero, de manera especial, por la sociedad civil que sufre el impacto de los procesos industriales. El conjunto de actividades extractivas llevadas a cabo por consorcios industriales con la permisividad de los gobiernos tiene consecuencias en las condiciones de vida y salud de la población en general. La apropiación y circulación de energía y materia a escala global tiene enormes consecuencias para la ciudadanía, así como para las estructuras de los sistemas / procesos metabólicos y la sostenibilidad a escala global, siendo posible construir un nuevo proceso de creación de conocimiento desde los estudios decoloniales. A partir de los ejes provistos con este marco teórico, este artículo propone resultados usando las herramientas metodológicas producidas por el proyecto EJOLT (www.ejolt.org) aplicadas, en este caso concreto, a los conflictos de justicia ambiental de Corea. Con este artículo sentamos las bases de la investigación en el campo de ecología política sobre conflictos ambientales, poniendo como novedad la aplicación de la investigación en el campo de los estudios asiáticos, en su aspecto más innovador, como es el caso de Corea. La estructura de este artículo parte de una reflexión metodológica sobre la investigación sobre conflictos ambientales, estudios decoloniales y la aportacion de EJOLT como herreamienta de investigacion. La segunda parte del artícuclo realiza una apliacion de este framework teórico al caso de los conflictos ambientales en Corea aportando dos estudios de caso referidos tanto a impactos ambientales como a las formas de articulación del discurso de protesta (Gumi y Dangjin).

Palabras clave: Historia Ambiental, Historia Decolonial, Justicia Ambiental, Conflictos Ambientales, Historia de Corea

\begin{abstract}
For years we have been developing several research projects in the field of environmental history, paying special attention to studies on environmental conflict. This gaze towards the resistance, in defense of the territories, has been assumed by NGOs, researchers, and academics but, in a special way, by the civil society that suffers the impact of industrial processes. The set of extractive
\end{abstract}


activities carried out by industrial consortiums with the permissiveness of governments has consequences on the living and health conditions of the population as a whole. Appropriating and Circulating energy and matter on a global scale has enormous consequences for citizenship as well as on the structures of Metabolic Systems/Processes and sustainability on a global scale, constructing a knowledged dialogue from decolonial studies. From the axes provided with this theoretical framework, this paper proposes results with the methodological tools provided by the EJOLT project (www.ejolt.org) applied to Korea's environmental justice movement and conflicts. With this article, we laid out the foundations of research in the field of political ecology on environmental conflicts, putting as a novelty the application of research in the field of Asian studies, in its most innovative aspect as is the case of Korea. The structure of this article is based on a methodological reflection on research on environmental conflicts, decolonial studies and the contribution of EJOLT as a research tool. The second part of the article makes an application of this theoretical framework to the case of environmental conflicts in Korea, contributing two case studies referring both to environmental impacts and to the forms of articulation of the protest discourse (Gumi Incident and Dangjin Coal Plant).

Key words: Environmental History, Decolonial Studies, Environmental Justice, Environmental Conflicts. , Korean History 


\section{Project Background}

Environmental Distribution Conflicts (EDCs), defined as "mobilizations by local communities against particular economic activities whereby environmental impacts are a key element of their grievances" (Scheidel, Temper, Demaria \& Martínez-Alier, 2018) have become widespread in several Asian countries in the last few decades. EDCs can also be important by contributing to broader sustainability problems in local and global contexts that are putting in question the impact of the capitalism/extractivism model. Although this is the most considered approach, environmental distribution conflict is a central point to building up new socio-ecological transition model after the natural resources extraction, at least at a local level (Scheidel, Temper, Demaria \& Martínez-Alier, 2018; Temper et al, 2018; Herrero \& Vilella 2017; Camisani, 2018). They are driven by changes in social metabolism, namely "the manner in which human societies organize their growing exchanges of energy and materials with the environment" (Martínez-Alier, Kallis, Veuthey, \& Walter Temper, 2010: 153). Precisely at this moment, anxiety for the future is a crucial theme of many books, reports and beliefs. Disequilibria are at such scales that no region in the world or sector of society can be beyond their reach. From its outset, it offers a theoretical and epistemological approach directed toward localizing and clarifying a new contribution to a history of the environment, while providing a detailed definition of the concept of social metabolism, which is under the lines of this article. The focus is on the exchange between society and forms of energy, matter, and information in a territorial spatial matrix across several scales, from local to global. Material dimensions of social change must be examined through the description and the study of different metabolic regimes that existed throughout history. Three types of metabolism are presented, and considered moments in the development of humanity from a socioecological perspective: cinegetic metabolism, organic or agrarian metabolism and industrial metabolism. Each type defines a social and ecological transmutation, becoming key for understanding our contemporary situation. The result is to present a theory regarding the direction, mode and pace of socio-ecological change, especially by showing how one metabolic regime moves into another through socio-ecological transitions, especially those leading from organic to industrial regimes. The last consideration of this methodological approach concludes by proposing visions of an alternative modernity, offering elements of a truly sustainable society, especially by rethinking the processes of transformation, circulation and consumption, possibly suppressing mechanisms of social inequality. Although such changes benefit certain groups, others suffer from falling livelihoods, environmental degradation, and worsening public health (Martínez-Alier et al, 2010). Recent transformations in Asia's industrial, economic, and social structures have spawned a wide range of EDCs, from largescale urban protests over facilities such as chemical plants and waste incinerators, to protracted struggles over industrial pollution in rural areas (Lora-Wainwright et al, 2012, 2017; Steinhardt and $\mathrm{Wu}, 2016)$. In addition, environmental justice frameworks have increasingly been applied beyond Western liberal democracies (see, for example, Carruthers, 2008), although rarely so in the case of China (for exceptions see LoraWainwright, 2017; Ma, 2010; Xie, 2011). 
2. Ecological Distribution Conflict. Reflections from the Citizenship Global Action

EDC areas are arising around the world connected with the Environmental Justice Movement. Only to contextualize this item, Global Whitness (2017) reported that more than 200 environmental leaders have been killed in 2016. Most of these leaders are contesting problems around unsustainable extraction, consumption resources of unequal local-global trade, being attended for their impact on standard living conditions. From a historical perspective, Guha and Gadgil (1995) called these who were/are resisting natural destruction as "ecosystem people" and Martínez-Alier $(2002,2005)$ considered them as the "environmentalism of the poor". Their resistance is being one of the most relevant contributions to the wider purpose, creating conditions to the media discussion around climate change, environmental destruction and the consideration around sustainable conditions, in local and global perspective. As Scheidel, Temper, Demaria \& Martínez-Alier (2018) explain this level of justice is central to the discussion around environmental justice, asking why, through, whom, how and when conflicts are taking an important role to the eco-social transition for the postcapitalism stage. The empirical approach is focusing on the level of energy and material extraction (previously noted Social Metabolism, Toledo and Gonzalez de Molina, 2014) with a non reductionist approach, i.e. only to a single issue, but taking into account the environment that surrounds villages, cities and local societies. Studying environmental conflicts is an elemental tool for understanding how people are being affected around the world and how these people are recovering the process of politicizing and resisting against the destruction of the surrounding environment (contesting with direct and performative action with a new protest language with similarities and differences between European, American and Asian context).

From a traditional historiographical perspective, the main question is around the identification of the actors, most directly involved in the conflictual dynamics, attending to concrete situations of unsustainable local conditions, reflecting over the causes of unequal distribution and environmental (in)justice. One conceptual element was the "political opportunity structures" that constructed the situation to promote the mobilization of several actors (McAdam, et al, 2001, 2004, Diani \& McAdam, 2003; Heijden, 2006). The movements constructed the "repertoires of contention" as the most logical action in response to historical and social adverse conditions (Tilly, 2002). Applying this consideration, the collective action is the central element for understanding the success of the social action or not. Reconsidering this perspective, as Scheidel; Temper, Demaria \& Martínez-Alier (2018) consider, the biophisical characteristics of the struggle are going to redirect the mobilizing action; resistance strategies may provide an advantage of "biophysical opportunity structures" that modify or disrupt the ecological damages. Tarrow (1992) concreted the "collective action frame", responding to environmental damages with a "vocabulary of environmental protest/ justice" that include concepts and slogans as "environmental racism", "tree plantations are not forest" or "keep the oil in the soil" (Martínez-Alier, Temper, Del Bene \& Scheidel, 2016). For their part, Pellow, Wenber $\&$ Schnaiberg (2002) focused their attention on few elemental points of environmental justice movement: 
a) importance of history of environmental inequalities;

b) role of social stratification by powerrace-class heterarchies (Grosfoguel, 2007)

c) role of multiple stakeholders in conflicts;

d) elemental position of marginalized groups in reshaping environmental inequalities.

Environmental justice movement emerged in the early 1980s in the USA as a non-violent resistance program against uneven distribution of environmental burdens in terms of class, gender of ethnicity, with attention to the dumping of toxic waste in urban afroamerican areas (Bullard, 1990; Bryant \& Mohai, 1992). This proposal, Environmental Justice, has received different attention, depending on the place, time or perception of the community at risk (Gottlieb, 2009). Grassroot Initiatives from religious, NGO`s mobilization or trade-unions consider environmental disputes as an adequate channel to canalize their reclamations against the impact of commodities in civilization. The language of the protest incorporates concepts from poverty, class, ethnicity, race or gender that underlie in local perspectives. Environmental conflicts received special attention in first and third world societies attending to the social unequal distribution in modern societies on a global scale. In most recent years, EJM (Environmental Justice Movement) has increased the level of attention to non-European societies, expanding perspectives, methodologies and societies suffering the "results" of Capitalocen in a wider context.

One of the other most relevant elements to construct this article is the study of violence in relation to environmental injustices. In line with his approach, Nixon (2011) notes this concept as "slow violence", referred to a delayed destruction across time and space, as well as with incremental, accumulative and exponential conditions (climate change, deforestation, etc.). Toxic effects on human health from pollution or open cast mining of use agrochemicals remains unseen until the accumulative impacts are visible, being especially difficult to identify the victims or/ and construct the social movement resistance. This is referring to a delayed destruction with relevant impacts on poor groups' conditions (Martínez-Alier, 2002), disarmed of the language of the "institutional" (global or local) forms of struggle against the impact of these phenomenon. "Ecological Violence" (Pelosi \& Watts, 2001) is described and conceptualized as the violence developed against nature, natural resources, deconstructing the physical relations and the fluxes of energy and materials in contemporary societies. As Nixon (2011) or Watts (2001) are explaining, the inequality of the social structure of violence are being derived, around the world, from unequal distribution of the effects resulted from negative externalities of the metabolism of capitalism. Studying the environmental conflicts is being converted in a key element to evaluate the distribution of social meanings and facilitate the consideration of these items as "manifestation of discontent that detonates when people organize [...] regarding not only unequal distribution of environmental benefits and costs" (Martínez-Alier \& O Connor, 1996: 160).

Considering Peluso and Watts (2001), "Violent environments" are integrating the intersection of environmental struggles, violence and power relations; reclaiming resistance against the destruction or dislocation of property over natural resources, labor or human conditions reflected on the control over their natural heritage. Phenomenon which is 
located in local social historical relations and connected with historical conjuncture.

This disciplinary commitment presents us, like others already before and after mentioned, challenges of transdisciplinary dialogue, betting to integrate in this vision the decolonial studies. On the one hand, there is a certain exhaustion and constraint towards socio-environmental conflicts of rural-peasant matrix. A second challenge is the vision on socio-environmental conflicts and the episteme, settled on understanding the logic of disputes over resources in terms of allocation of capital-natural income in the prevailing modes of use (Ortega, 2002, 2007, 2012). It is obvious that this approach has a Eurocentric matrix focused on dismantling peasant communities of any form symbolic-cognitive relationship with the territory, turned into mere subjects of predation of resources, omnivores of the ecosystem. But it prioritizes a "colonial" vision of environmental conflicts (Ortega \& Olivieri, 2016), led by hiding the role of women in these disputes. To start analyzing the most referencial works on decolonial thinking also called the Modernity/Coloniality project, decolonial project or, receiving influence from a parallel school with epistemologically similar and complementary objectives, Epistemologies of the South - it is essential to look towards classic authors about colonialism - in this case, regarding Latin America and the Caribbean.

Based on specific corporalities in territories with socio-environmental disputes, the introductory chapter of The Decolonial Turn (Castro-Gómez \& Grosfoguel, 2007) brings us closer to the way in which colonialities that have not yet been extinguished after the departure of officially colonial regimes.

Hence, the concepts of "decoloniality" and "world coloniality" are presented as a denunciation of the Modern-Colonial WorldSystem —capitalist/patriarchal/state-centric/ north-centric/Christian-centered-development, of the Eurocentrated forms of knowledge and racializing hierarchies that emanate from it spreading and imposing from the developed nations towards an oppressed periphery (Castro-Gómez \& Grosfoguel, 2007: 14). EuroCentred Paradigm Science -northcentric, we would say here- has been constituted as universal, omitting, making invisible, trivializing and/or silencing all "epistemic otherness", the plurality of paths originating in what is considered periphery, and that the hybris of the West Countries (CastroGómez in Castro-Gómez \& Grosfoguel, 2007: 83) has discarded. Overcoming this hybris enables us to deconstruct the epistemic dichotomies that divide knowledge between "scientific", "legitimate", "useful", and "ancestral" knowledge, with no scientific validity and, therefore, with no universal applicability (Escobar, 2012: 34).

The universal concepts, as well as the imposition of this World-System logic, with the consequent logic hidden under the rhetoric of modernity, necessarily generates a response on the irreducible energy of humiliated, vilified, forgotten and marginalized human beings. Decoloniality is, then, the energy that cannot be managed by the logic of coloniality. Therefore, the aim of the decolonial authors is to "decentralize Europe" and to establish a North-South and South-South dialogue to break with the hierarchical categories of Capitalist Modernity (Santos, 2010; Santos \& Meneses, 2014). Starting from the various historical, political, epistemic and ontological specificities, the decolonial matrix projects apply to different areas of human life and social relations. The glocality of the socioenvironmental resistances and sustainability approaches makes it conform as a multitude of 
practices and realities, experiments and contingencies, which tend to focus on their close surroundings, while continuing to establish ties of communication and solidarity with territorial projects and environmental common futures in other places. Nevertheless, they are mired in the perversity of the rules imposed by the same World-System.

The land, the space that is inhabited, the ways of managing it by the communities acquire, in this context, an epistemologically worthy and de-hierarchical value, which influences the way of conceiving and selfconceiving as a community. Colonization and the mechanisms of coloniality, have imposed changes in the relations with the natural environment, turning "particular ecosystems" into "modern forms of nature" (Escobar, 2012). Since the ways of life of the subaltern groups are subject to the modern / colonial model, the objective of these studies is precisely to redignify the community attempts of survival and resistance, vivifying the environment as one of the subjects oppressed by the mechanisms of capitalist modernity.

The environment as a social construct in the relations of production, appropriation, and distribution of goods through the sociometabolic relations in each historical moment, is precisely the axis around which this concluding chapter is developed. Previous research participates in the formulation of alternatives and effective proposals to claim the historical debt of colonization in distributive conflicts and ecological problems. From the Global South, and the different contexts in which we live, we manifest the need to cooperate to build a more just society(ies) free from all oppressions.

Escobar (2014) presents a series of epistemological challenges that cross our conceptual view of capitalist modernity. The Modernization theory places us in the methodological certainty of the benefits of capital, science and technology, especially from the post-structuralist baggage in which the sures (Souths) were "invented", shaping reality as a strategy of cultural, social and social domination. So, Escobar establishes that it is necessary to question the knowledge practices regarding development and modernity.

This epistemic and political verdict puts us in front of the mirror of Modernity with the prism of decolonial studies. It appears as a research program that is located in postextractivism, transforming the social and political imaginary. As the critical approach to Modernity indicates, a systemic decolonization is necessary (in terms of the genesis of knowledge production itself), going beyond the intra-European and intra-modern perspectives that reconfigure the culture and the dominant episteme.

The violence against community uses, later criminalized or extinct due to the coercion of the State, gives us indications of practices that may have a new reproductive capacity for certain communities. They indicate new practices of socio-environmental sustainability that can be valued from an intuitive perspective towards the reasons for their eradication or subordination to an industrial management of ecosystems. It is a counter-hegemony history, of the emancipatory resistance that can expand the present of many societies, rehabilitating practices of doing and governed by common interest or perception of their needs inside the territory where they live.

This position, of hegemonic primacy of the Modernity discourse, not only perpetuates the hegemony of the discourse on the superiority of Western civilization, but also responds to a process of reconfiguration of strategies of colonial domination, a global coloniality. To understand it, it must be clear 
that "colonialism" and "coloniality" are not the same. As indicated by the Colombian academic Aníbal Quijano (1991, 1999, 2000, 2001), while "colonialism" denotes a political and economic relationship in which the sovereignty of a nation or people rests in the power of another nation, which makes the latter an empire; "Coloniality" refers to a set of longlasting power patterns that emerged with colonialism but define culture, intersubjective relations, the distribution of work and the production of knowledge beyond the strict limits of colonial administrations. For his part, Santiago Castro-Gómez (2007: 79) points out that the hegemonic discourse of the civilizational model is articulated through a triangular structure between the "coloniality of knowledge", the "coloniality of power", and the "coloniality of being". That is why it is necessary to decolonize these three spheres. Seen this way, the processes of political decolonization that the countries of the "Global South" have gone through do not exhaust the problem of existing coloniality. This is the essence of the decolonial critique or perspective of modernity/coloniality, which has been shaped by the critiques that Quijano (1991) gave to the "theory of the modern world system" from the notion "coloniality of power". It is an approach that highlights the fundamental role of colonial expansion in the epistemic conformation of modernity and reveals the Eurocentrism of the globalized civilizational project. In fact, Wallerstein (2009) has continued to develop it. The decolonial criticism states that, after the end of colonialism and colonial administrations, a world-system has been consolidated where Western epistemology dominates over the rest of the epistemologies; hegemony founded on the long-lasting imperial history that built Western man as a subject of superior enunciation and pattern of supposed universal validity, capable of dictating the norms of all world human existence.

As for the "coloniality of territorial power", must be approached, following Mignolo (2000, 2000a) as the field of intersubjectivity in which a certain group of people define what is territorially correct and, therefore, sustains the power in global territorial scenarios and in local ones. In the former, the actors who hold control over the processes of exploitation of natural resources, large open-pit-mining OMG's, megahydraulics projects, etc., sometimes supported by the legitimizing role of creation spaces, operate as transmitters and executors of this process. On the local side, there are those who can from the outset exercise public policy processes, contextualized in the closest territory. This territorial coloniality is effective generating hierarchies in the territory that are supported by genealogies of knowledge that opt for the primacy of Western epistemologies, which hierarchize knowledge about the territory, embedded in a logic of neoliberal globalization, in a science that continues to parcel the scientific knowledge as a basis for the continuity of the paradigm of modernity and postmodernity. The possibility of conceiving the territory from a "frontier thought" to modernity/coloniality, lies in the possibility of a total territorial decolonization, it would imply breaking the triangle of territorial coloniality and replacing it with a just and sustainable conception of the relations between powers, knowledge and territorial beings, both globally and locally.

The look on the distributive ecological conflicts is based on three methodological axes that form the basis of this article, with reflections from the field of political ecology to which the methodology, explained below, responds. Secondly, the study on the dimension of the collective response to the consequences 
of Capitalist Modernity that is underlying the studies of socio-environmental conflict and how the living conditions of societies and human groups are affected by locating in the Global South. Being a central axis of this element, the forms and languages in which the resistance is articulated from the human groups to those conditions created by the industrial capitalist civilization.

Lastly, the third axis, as a result of all of the above, Capitalist Modernity with a Eurocentric matrix has articulated a form of sociometabolic appropriation of natural resources that we can qualify as Colonial. Beyond political systems and socioenvironmental realities, nature within the framework of capitalist civilizational systems is an object of appropriation, stripped of concrete conditions of life and semiotic values for extra-European communities. Capitalizing on nature is a condition embedded in the logic of the industrial system on a global scale and there are many societies that suffer the negative externalities of this global commitment.

\section{Methodology}

We propose using the EJAtlas database (www.ejolt.org) to gather and analyze environmental conflicts in an American and Asian context. The analysis is focused on one project that provokes environmental damages or impact in a concreted area and where people, suffering the results of the project, organize themselves to resist against it. In our case, searching information has been developed using non-direct information, refusing the collaborative dimension of EJAtlas project, and applying the methodological approach of environmental history. First step was the searching of information dated from international experts and after that, enter the cases based on secondary sources. From our background, we developed this approach in several geographical areas especially Southern Europe and South America, now applied to the Asian Context.

The Database incorporated more than 100 variables to compare and analyze (Martínez-Alier, 2016), describing the type of conflict, date of beginning, area of impact (rural or urban) and "mobilizing group". With these initial variables, intensity of conflict may be measured, incorporating the dimension of latent level, local or medium organizing level (street or protest local) and high level (with mass impact mobilization), resulting in a more complex information with internet links. Inquiring direct forms of violence resulted from outcomes or pollution or environmental damages. Criminal actions, repression against poor societies or direct impact on citizenship in urban, rural or urban areas refers to a wide distorted accusations referring to activists. Most of them, in the specific case of Asian countries, don't reflect direct actions. We want to focus on reasonable fear materialized according to technical reports, regarding environmental, socio-economic and health consequences, inserted in a qualitative framework. Above all, and the specific case of Asia, EJAtlas methodology, has limitations, some of them being assumed by authors as an important element to be resolved. Data available is limited and with complexity for being obtained with a not homogeneous coverage in global sense, being difficult to compare between countries, and being necessary to broaden geographical mapping. As Del Bene et al indicates (2018) discussed cases are primarily concentrated in South and Southeast Asia, Central South America and the Balkans, but African Countries, China, East Asia and Russia have a lower number of cases, due to the difficulty to obtain information from 
these areas. Many of these societies, nowadays industrial economies, are needing new resources of energy and materials, modifying and growing the level of exchange of energy and material with their environments (FischerKowalsky, 2011). These new "commodity borders", well exemplified in Asian territories not only in Nation-State frontiers, are suffering intense process of unequal distribution of material and as result ecological distribution conflicts (Spiric, 2018). Most of the studies around environmental conflicts and justice are located in the world's periphery, economically and environmentalist not central position. But in this moment, we reclaim an overview over industrialization or economic diversification, not central or new central in the new global order. According with this point of view, the environmental organizations are attending the causes of the increasing number of environmental distribution conflicts around the world and the transformation of the metabolism of the economy (Martínez-Alier et al, 2016) based on the main idea that these conflicts are mobilizing the response to unsustainability items, both in socialism and capitalism models, but responding to emergent threats to living conditions.

\section{Introduction to Case Studies in Korea}

Socio-environmental research arises from the concern or anxiety to understand the way in which other different societies struggle with environmental problems (Giehae Choi, Seulkee Heo \& Jong-Tae Lee, 2016). The current capitalist system is damaging nature and citizens who have been forced to change their quality of life. Future generations are the most affected. It is a struggle for environmental justice. The Dangjin coal-fired plant is selected for this research due to the importance that
Korea has in the world and all the changes it is making in energy and environmental issues. In recent decades we have observed an increase in environmental conflicts related to installations of power plants of all kinds in different countries. South Korea has experienced rapid industrialization and urbanization and has therefore needed to increase its energy consumption. About $98 \%$ of the consumption of fossil fuels is imported and has subsequently caused undesirable use of land and environmental pollution. In South Korea environmental conflicts originated commonly in areas close to industrial zones. Since the launch of the program National Political Projects, the environmental movements that began in industrial areas were dispersed to rural and metropolitan areas (Chu, 2003). A large number of these projects were planned and decided by a few politicians or government officials without listening to or reflecting the opinions of interested parties or the general public. Considering that coal power plants are one of the largest sources of anthropogenic mercury emission into the atmosphere (Pudasainee, Kim \& Seo, 2009), South Korea suffers from severe pollution caused by fine particles from coal power plants. This has caused the Korean environmental movement to become a power that is rebuilding and transforming social, political and cultural structures $(\mathrm{Ku}, 2011)$. At the same time, we can observe how the construction of a hightech industry is having a considerable impact on the livelihood of rural and rurban population (Kim, O’Neill, Lee, Cho, Kim \& Kim, 2007) as exemplified by the conflict arising from the Gumi Plant Incident. The lack of preparation and security measures regarding these industries have been a source of conflict clashing with the need of the State to impose a concrete productive system. 


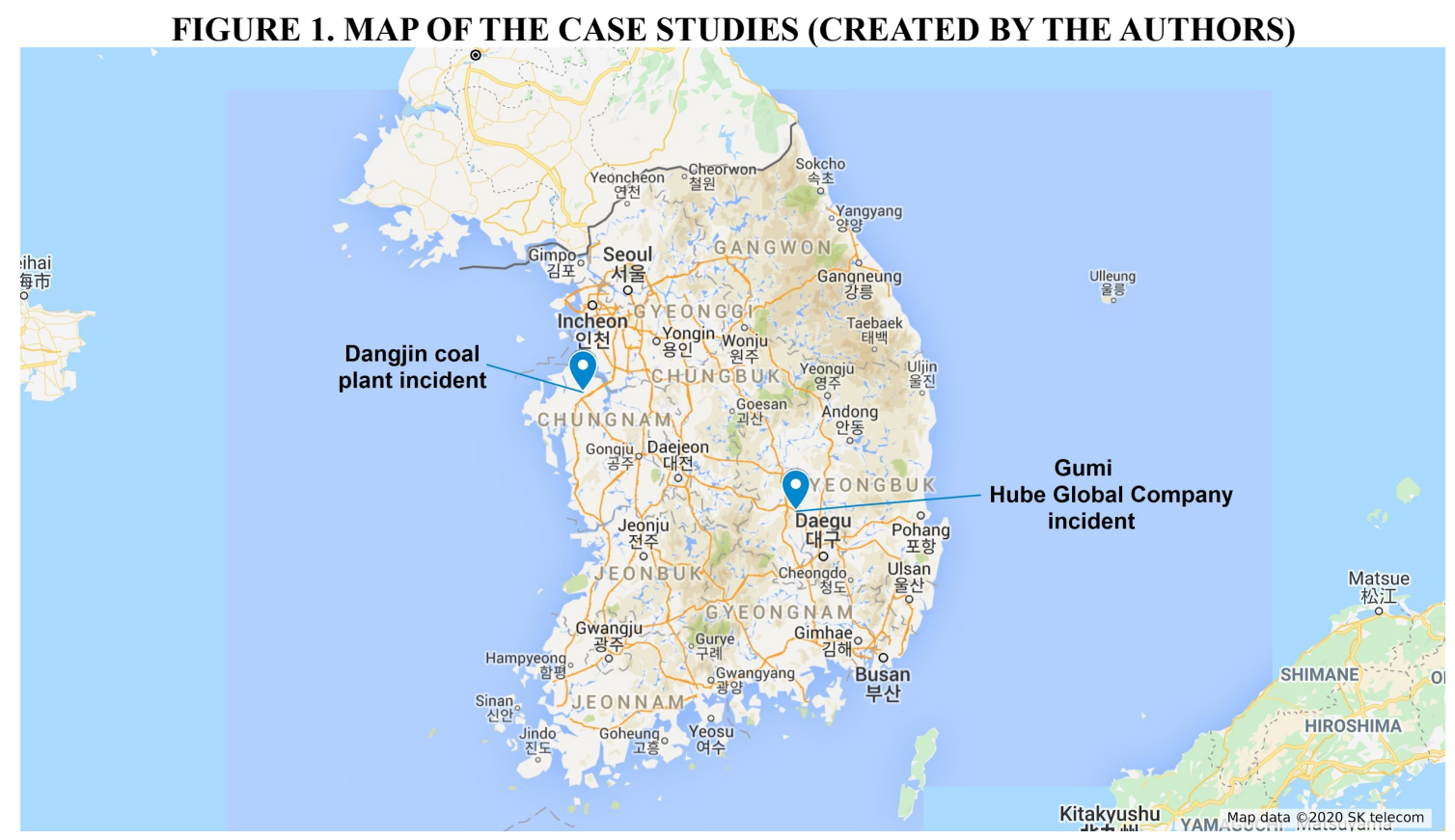

\subsection{Dangjin. Coal Power Plant}

Dangin is a city located in the south of Chungcheong province on the southern shore of Asan Bay. Its name means "Tang Ferry" and it refers to the historical relationship of Dangjin port with the other side of the Yellow Sea. Its economy is based on a mixture of agriculture and heavy industry. This power plant can be considered as one of the largest plants in the world. Of the 59 plants in the country, 26 are located in this region. It provides 6,040 MW of bituminous carbon fuel and includes ten units (Power technology, 2019).

The construction of the first two units began in May 1995 and were completed in 2000. Units 3 and 4 were completed in 2001. Units 5 and 6 were built during 2006, and a year later, the next two units. In May 2019 the construction started units 9 and 10 .

With a total investment of 2.7 billion dollars Korea Electric Power Co (KEPCO), the engineering subsidiary, was the main architectengineer. It provided services ranging from preliminary plant design to start-up and testing, based on a standardized once -through supercritical boiler plant design with variable pressure operation capability. More than $85 \%$ of electric power is currently generated by KEPCO. It is the largest power company in South Korea responsible for the generation, transmission and distribution of electricity and the development of electric power projects. KEPCO is responsible for $93 \%$ of Korea's power generation. The government of South Korea (directly and indirectly) holds a 51.11\% share of KEPCO.

The Dangjin power plant is equipped with very sophisticated equipment to eliminate carbon dust. A low NOx burner and two-stage combustion reduce nitrous oxide in the flue gas. Particulate air pollution is controlled with coal dust suppression equipment, an electrostatic precipitator and high batteries. The flue gas also passes through desulphurization and denitrification scrubbers (Kc Cottell, 2019). Water pollution is controlled with wastewater treatment plants in the facility. Silencers and soundproof walls control noise pollution. 


\subsubsection{Nature of the conflict}

In order to understand this conflict of urban or semi-urban nature, it is framed as a socio-environmental conflict "induced by the environment" due to the contamination caused by previously mentioned plant (Homer-Dixon, 1991).

Environmental conflicts are manifested as political, social, economic, ethnic, religious or territorial conflicts, or as conflicts around resources or national interests. They are traditional conflicts induced by a degradation of the environment (Homer-Dixon, 1991: 82)

Taking into consideration this line of thought, the conflict around the Dangjin plant arises as a consequence of the risks of contamination for those whose environment is the main basis of sustenance (Guha \& Martínez, 1997). In the same way it has been the paradigm that shows how environmental problems are becoming more evident because environmental awareness has spread in all sectors of society (Jones \& Dunlap, 1992).

This example of resistance began on March 3, 2016. It emerged as a response to the government's decision to expand the existing power plant with new units, which had been in operation since 2000. At the beginning of the conflict the government, instead of going to the root of the problem, moved the affected people to other areas (Kim, 2008).

On the same day, a group of environmental activists held a theatrical performance in the streets demanding the cancellation of the new coal plants. The protests against this plan continued on March 8 and continued for the rest of the month. A year later, on March 24 and 25, approximately more than 1,000 protesters comprised of citizens and students, marched with banners. Specifically, on March 25, protesters, activists and politicians gathered at the Dangjin Culture and Art Center to express their dissatisfaction with the coal-dependent policy, demanding the government to cease the use of coal.

One month later, in April 2017, Mayor Kim Hong-Jang criticized the government's plan to add two more units to the plant. In the face of criticism, the delegates of Samcheok reported the opposition to the plan for a new coal plant near the coastal city.

Local groups prepared a referendum and joined the movement "Break Free" to try to stop it (Jackson, 2017). During that year, large mobilizations against government policy took place. After the Candle Revolution, from October 2016 to April 2017, the new president, Moon Jae-in, ordered that for the next 30 years the power plant would close for a month every year. However, despite the efforts, the reality seems to be very different. The government announced that by the year 2025 there would be a reduction in the use of coal and the closure of ten old plants. Nevertheless, the Ministry of Commerce, Industry and Energy and SK Gas intends to build nine new plants by the year 2029. The citizens are convinced that the new plants will have more capacity than those that are being closed down.

\subsubsection{Social and ecological implications. Protest and Disputes}

The protesters of the conflict are citizens and neighbors, who are the main population affected by the pollution caused by the plant. They are joined by social movements and various environmental groups such as Greenpeace, KMET and the "Break Free" movement, as well as the intervention and support of international environmental NGOs, although it is true that the environmental NGOs of South Korea are the most active in regional and international politics compared to 
those of their neighboring countries (Wu, 2013). Similarly, political figures, such as Minjoo Party legislator, Eoh Kiyku, mayors and university professors belonging to the Institute for Environmental Research, such as Lim Young-Wook, have been active players in this cause too.
The demonstrations that these groups have used to carry out a visible mobilization were varied, from creative or artistic actions in the form of theater or murals and mass protests on the street to active activism in the media. They also organized consultations with local citizens and referendums and marches.

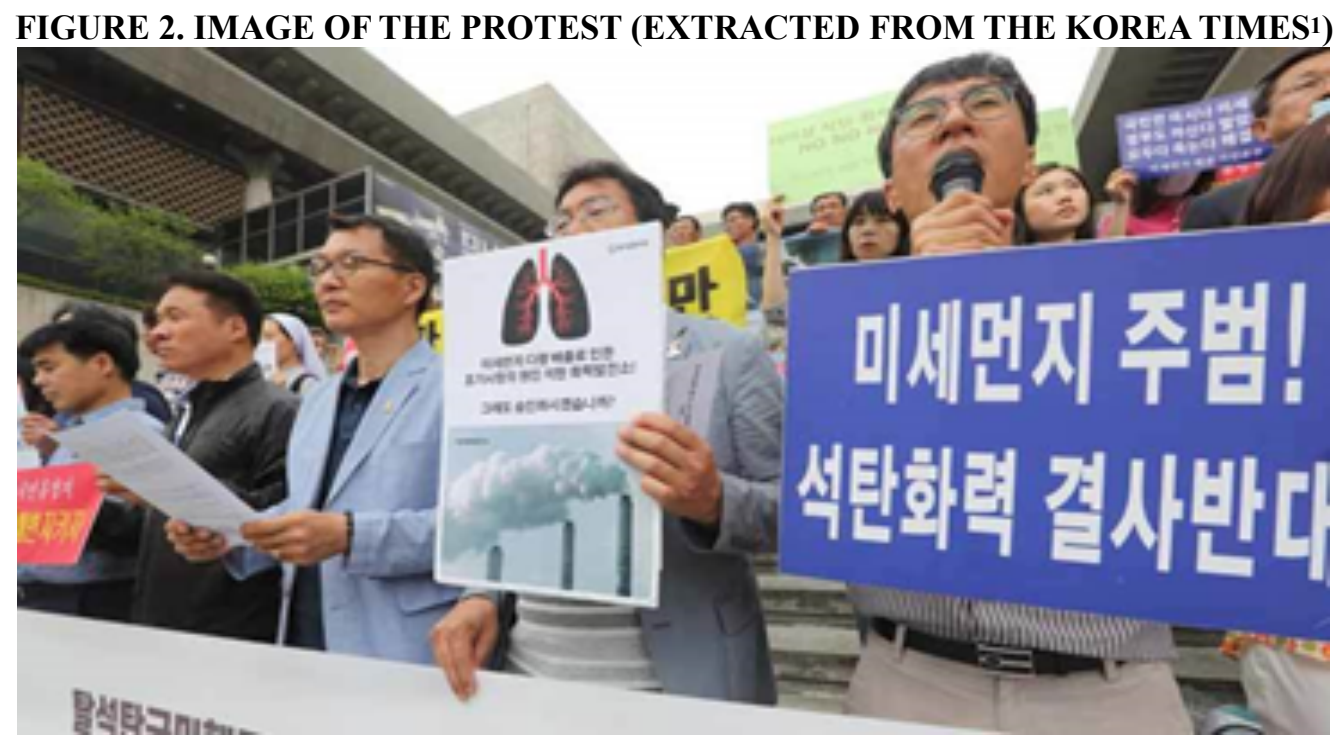

Protesters complain about the need to wear masks to go out on the street. They are convinced that the pollution caused by the power plant is the main health problem amongst the inhabitants. The absorption of fine particles through the respiratory system can be the most dangerous risk. They want to close down Korea's largest coal power plant.

According to Greenpeace Korea last year, 12 people have died and 23 have suffered from cancer in this region as a direct result of the pollution from the power plant (The Korea Times, 2017). According to public health reports conducted in Chungcheong province, residents of Dangjin had the highest rates of cardiovascular and respiratory problems compared to other regions. As of 2014, coal plants provided $39.1 \%$ of all electricity generated in Korea. According to OECD report, this air pollution could cause more than 9 million deaths by 2060. Falling just behind India and China for the highest mortality rate.

According to a report from the Ministry of Trade, Industry and Energy, with the Seventh Basic Electricity Supply Plan (Motice Notice, 2016), the government plans to reduce from 39.1 to $31.8 \%$ emissions by 2029 . However, the continued construction of new plants with 20 units will be completed in 2029 . It will close ten old plants by 2025 to reduce emissions. But the new ones will have greater capacity than the ones that are being closed.

1 The Korea Times (2017, May). Retrieved from http://www.koreatimes.co.kr/www/nation/ 2017/05/371_230056.html 


\subsection{The Gumi Incident in South Korea}

Hube Global Company established its factory on the Gumi City's National Industrial Complex (Invest Korea) in the year 2008 in order to produce hydrogen fluoride, which is a strategic resource for the creation of silicon chips. The Gumi branch of the Citizens' Coalition for Economic Justice complained about this project, since the purpose of the Industrial Complex was to establish high-tech enterprises and the production of chemical products wouldn't fit this description (Koo \& Kim, 2012). Nonetheless, the establishment of this enterprise was the product of a national tendency to expand the industry of hydrogen fluoride because of its use to manufacture chips, which is strategic in South Korea's market and its development towards an industry of high-tech components.

On the 27th of September of 2012, there was an eight tons of hydrogen fluoride gas leak, which dissolved into the moisture of the air to form corrosive hydrofluoric acid (Park, 2013), this took place at Hube Global Chemical Plant, located in Gumi's Gongdandong district (Gaudioso \& Stewart, 2015; Park, 2013). This accident occurred as workers were transferring the gas by hoses from a tank lorry to the factory, causing an explosion. (Yonhap Editorial, 2012). Due to the nature of the gas and the lack of equipment, 5 workers died at the moment of the accident and 18 (taking into account both security and plant workers) were injured, suffering from immediate and permanent lung and eye damage. At the same time, an estimate between 3.000 and 12.000 residents of the zone would be directly affected by the consequences of this gas leak.

This issue has become a national problem due to the rise in these types of accidents in the year 2012, increasing by $40 \%$ compared to the previous year (Yonhap News,
2013/05/27). This issue, according to experts, needs a multiple solution approach such as regulation and the training of professionals as to use the means necessary to avoid and/or contain the accidents. This fact is especially relevant in this accident since firefighters were unable to use calcium hydroxide on the first day to sort the crisis as they were not prepared for such an incident and did not have this product available for use (Park, 2013). Concurrently, government and local response was especially negligent, as residents were waiting up to 4 hours for evacuation after the accident. They returned to their homes the following day, after an insufficient evaluation of the damage it could have caused. For this reason, local residents (Yonhap News, 2012/10/06) were exposed to the gas and started to complain about symptoms, which doctors of the Association of Physicians for Humanism (Koo and Kim, 2012) said could end up in serious health problems such as arrhythmia, presence of lung fluid or long-term lung disease. 11 days after the accident the zone was declared "special disaster zone" (Yonhap Editorial, 2012) by President Park Geun-hye, following the information of the Central Safety Measures Committee (Koo and Kim, 2012), and the residents were relocated again, not to return until the end of December of the same year, as the gas concentration descended. The cleanup labor had to burn 9100 tons of crops (Yonhap Editorial, 2012) which would in turn be another of the factors alluded by the residents, in order to ask for compensation, as they also had the materials prepared in advance and would lose all of their income. Along with this, 1300 cattle (Yonhap News, 2012/10/05) were heavily affected by the gas and experienced drooling and symptoms similar to those of the common cold. The arrival of the local population on December of the same year 
prompted the immediate return to agriculture and Hube Global's plant labour. Experts such as Neal Langerman (Park, 2013) of the Consulting Company on Advanced Chemical Safety in California spoke about the chaos of the incident, the necessity of regulation and preparation. He also warned about the return of residents, 3 months is not enough time. He talked about the need of a constant evaluation of air quality while other associations such as the Gumi Nakdong River Community (Koo \& Kim, 2012) warns about the water sources, though there's still no sign of contamination, and calls for constant control of the Nakdong River, which is located $1.5 \mathrm{~km}$ away from the plant, and provides water to 10 million people. The Citizens' Institute for Environmental Studies, a branch of the Korean Federation for Environmental Movement, asked for disciplinary actions to be taken against the Minister of Environment and the National Institute of Environmental Research (Koo and Kim, 2012) since their measures and actions were insufficient and they put the population in danger. Nevertheless, this petition has not come to any significant conclusion. The Government under Parliamentary Control promised to establish new legislation on Chemical Safety and the creation of local centres to control these accidents (Park, 2013).

As previously stated, this accident has direct national implications as it happened in a year when these types of incidents surged. This is the result of an exponential increase of the hydrogen fluoride market, which resulted in the creation of 545 enterprises, that produced and distributed this product in 2011 as opposed to the 26 that were functioning in 2001, according to the Ministry of Environment. The need to produce this chemical substance is directly related to the high-tech market, and it is needed for the production of silicon chips as to embed patterns on them. The accidents were caused by a lack of instruction for workers and it was serious enough as to end up categorizing the area as a "special disaster zone". Thus, the project was momentarily stopped in order to assess the consequences, although the evacuation of the personnel working in other companies of the Industrial Complex and the local people was considerably long. Nevertheless, the assessment which was enacted was in many ways deficient, only considering the air quality, which in turn resulted in the return of local people and exposing them to the contaminant. Due to the health problems and the damages caused to the environment surrounding the area, such as cattle and crops, the zone was established a "special disaster zone" for two and a half months, also insufficient in many ways as to ascertain the consequences. This lack of consideration for the workers and local people was even more dangerous since the plant started to function as the population returned to their homes. This period of time was insufficient in many ways, as to inform workers, change or provide protective equipment or establish legislation, taking into consideration the magnitude of the incident and the reiteration of it. Although the Government has given 36,4 billion won $(32,555,250$ USD) for the citizens and enterprises as compensation for their loss, and big companies such as Samsung, Hyundai, LG and others (Yonhap News, 2013/07/05) have made a decision to invest in these factories and to provide them with safety equipment and proper facilities. The rapidness of the return to the project makes it impossible for the enactment of the measures. In 2013 there was still $40 \%$ of chemical companies that were vulnerable to fatal accidents. Other projects were put in place as to try to prevent these accidents, such as the agreement to receive assistance of civilian experts in chemical mishap (Yonhap News, 
2013/07/24), which was established by the Ministry of Environment along with the Korean Chemical Society. Nevertheless, due to the distance to the factories, most of the experts would have to travel a long distance, which would have made an immediate response impossible. For this reason, associations of experts and environmental societies call for more investment in a local context and the instruction of the professionals, who have to deal with the material on a day to day basis.

Finally, we would like to mention the establishment of new laws concerning the environment and chemical accidents as it was prompted by multiple accidents in 2012 and especially the case of Hube Global in Gumi. These laws would comprise the amending of the "Chemicals Control Act" (CCA) and the creation of the "Act on the Registration and Evaluation, etc. of Chemicals" (AREC), which were promulgated in the first half of 2013 and enacted January 1, 2015 (Ministry of Environment, 2013-2014). The reinforced management of Chemicals and Chemical Accidents provided a series of new regulations: the toxic chemical business permit with its reports and risk management along with the required facilities, equipment and staff, increased fines as to "enforce responsibility", an every 5 years a risk management plan for the handling of chemicals, a more severe rule to report emergency and taking action through an associated institution (previously only those cases in which human or environmental risk were considered had to be reported), the establishment of special control zones in vulnerable areas, the creation of the National Institute of Chemical Safety (NICS) which is created for prevention and response through training programs, and, finally, the improvement of the Chemical Accident Response Information System (CARIS) to have a more integrated and interconnected control system. Concerning the Act on Registration and Evaluation of Chemicals the new legislation created would require reports of purpose when handling more than 1 ton of chemical substances, the necessity of registration of manufacture and import and a toxicity evaluation and risk management by classifying the products in categories such as: poisonous, permitted, restricted or prohibited. With these measures the Government tries to establish a more direct way to communicate with business and ask for responsibility in case of an accident (Ministry of Environment, 2013-2014).

Although this incident has been strictly resolved in terms of legality (even though it is not clear that all of the locals who claimed compensation have received it), the consequences and the decisions taken in 2012 bring us to the conclusion that the means used were insufficient and prompted by economic interest. We see a double course of action: the first was the lack of preparation and thus the accident and problems surrounding the evacuation, which we could argue are signs of not acknowledging the issues it could cause to the population, and a second which was the response after the outcry of local people and local environmental associations. This second response in turn gave way to a broader compensation and the establishment of investment by big companies in order to avoid further retaliation, as well as the legislation in order to establish a tighter control on businesses that handled chemical products. Nevertheless, as we have stated, the return to the chemical plant as well as the local population in a 2 -and-a-half-month period after the "special disaster zone" proclamation indicates a lack of interest in the immediate application of these preventive means. The return of the population could have given way 
to diseases, as the environmental associations warned of the insufficient testing of the environment such as a constant evaluation of air quality and the possibility of river contamination.

At the same time, the resumption of work at Hube Global's Chemical Plant would be under the same circumstances as the evaluation and training of personnel, as well as the preparation of infrastructure and equipment would be impossible to accomplish in such short notice and without the help of proper institutions in the process. Even though some of the plan provided by the government conveys a deep understanding of the underlying problem, such as a clear consideration of local importance and the need to have instructed personnel, the application of a stricter regulation in order to protect the locals, the workers and the environment were non-existent in an objective way as economic interest would be more relevant. Thus, we consider that this problem was inadequately responded to and could have given way to severe unreported consequences.

\section{Concluding Remarks}

With respect to the methodological framework, Korea Case Studies, noted above, are spreading the dimension of the global (in)justice movement in Asian Studies. First conclusion is remarking the global dimension of environmental impacts on local communitiescitizens. These socio-environmental impacts are reflecting the negative externalities of the extractivist model on a global scale, and provokes social disputes or protest against the effects on human health. This pattern of social protest has similarities between European, American and Asian context. Another conclusion provides a necessary reflection about the colonial model of the extraction of natural resources as a condition for the continuity of capitalism as the civilization model. Nowadays, in the beginning of $21 \mathrm{st}$ century, colonial structures are based on the new wave of extraction of natural capital, not only from the South, but from a geographic consideration, known as the Global South, perhaps countries or social groups in the Northern Global Countries. Decolonial disputes are fighting for the defence of territories, health and living conditions, not affected by pollution activities by putting in rise all the community. For this reason, decolonial approaches and perspectives must be included in environmental justice movements, due to many protests in several territories that are being "decolonial disputes" for themselves.

The conflict unleashed by the Dangjin plant is an example of resistance in favor of environmental Human Rights, as a "planetary right" to protect the interests of future generations. The emergence of actions and movements of civil societies in direct response to environmental activities and specific social injustices offer us the opportunity to consider how to better understand the issues of social justice and the political decisions that demand social action, with a view to mutual commitment, dialogue and transformation (Graeme \& Harris 2015). Although the Korean government has developed several measures against pollution, including the Environmental Health Plan 2006-2015 (UN Environment, 2019), at the same time it needs to conduct an investigation of environmental health and to elucidate the causal relationship between pollution and health damage (Nihon Kankyo Kaigi, 2009). Last year, a national audit revealed that up to 28 percent of fine dust, particularly PM 2.5, covering Seoul and the metropolitan area could be attributed to coal power plants on the west coast. Asian societies 
will determine much of the future of human impacts in the regional and global environment. Let us not forget that the environmental impacts in Asia are due, in part, to the integration in the global capitalist system, with its highly interconnected to transnational networks for the extraction of natural resources and for the production and distribution of goods (Graeme \& Harris 2015). Therefore, in light of the results, we dare to state that this conflict has not achieved success in environmental justice because the coal-fired power plant has increased its units and is being expanded until 2029 according to governmental plans. People will continue their protest against this expansion. In the case of the Gumi Incident, it highlights two central elements in the field of the evaluation and study of socio-environmental conflicts: the appearance and, in many cases, inadequate or manipulated evaluation of expertise knowledge when measuring the socio-environmental impact; and secondly, the practice of inserting the problem in the context of judicial litigation. Both spheres tend to be in many cases complementary when it comes to dismantling or canceling the practice of organized civil resistance against environmental damage.

Finally, these socio-environmental conflicts show how the long hand of capitalist modernity embraces all the territories of the Earth. Industrialization processes with high levels of contamination or environmental risk, externalities that are highly negative for the whole population (life risk, associated diseases, soil and water destruction, etc.). They are the language in which the logic of territorial appropriation of capitalist civilization is expressed. Impacts that give rise to struggles, resistance, lawsuits and changes in environmental protection legislation systems as a mere recomposition of a coloniality of the territory that threatens bodies and living conditions.

Capitalism, Industrialization and Modernity are plots of a form of objectification of nature, dispossessed of reproductive values and symbolized as a mere object for extraction of flow of material and energy.

\section{Bibliographic References}

Bryant, Bunyan \& Mohai, Pau (1992) Race and the incidence of environmental hazards; time for discourse, Colorado, Westview Press.

Bullard, Robert (1990) Dumping in Dixie. Race, Class and environmental quality, Colorado, Westview Press.

Camisani, Paola Bianca (2018) Sri Lanka: a political ecology of socio-environmental conflicts and development projects. Sustainable Science, Issue 3, pp 693-707, DOI: https://doi.org/10.1007/ s1162 5-018-0544-7.

Castro-Gómez, Santiago \& Grosfoguel, Ramón (comp.) (2007) El giro decolonial: reflexiones para una diversidad epistémica más allá del capitalismo global, Bogotá, Siglo del Hombre Editores, Universidad Central, Instituto de Estudios Sociales Contemporáneos y Pontificia Universidad Javeriana, Instituto Pensar.

Carruthers, David (ed) (2008) Environmental justice in Latin America: problems, promise, and practice, New York, Cambridge University Press.

Diani, Mario \& McAdam, Doug (2003) Social Movements and Networks: relational approaches to collective action, Oxford, Oxford University Press. 
Escobar, Arturo (2012) Más allá del Tercer Mundo. Globalización y diferencia, Bogotá, Instituto Colombiano de Antropología e Historia.

Escobar, Arturo (2014) Sentipensar con la Tierra. Nuevas Lecturas sobre Desarrollo, territorio y diferencia, Medellín, Ediciones UNAULA.

Fischer-Kowalsky, Marina et al (2011) Methodology and indicators of economy-wide material flow accounting. State of the art and reliability across sources, Journal of Industrial Ecology, 15(6), pp. 855-876.

Gaudioso, Jennifer \& Stewart, Christian (2015) Chemical Safety and Security (No. SAND2015-20841C). Sandia National Lab.(SNL-NM), Albuquerque, NM (United States). [Online] https://www.osti.gov/servlets/purl/1244860 [Accessed February 20, 2020]

González de Molina, Manuel \& Toledo, Victor (2014) The Social Metabolism. A SocioEcological theory of Historical Change, London, Springer Publisher.

Giehae Choi, Seulkee Heo \& Jong-Tae Lee (2016) Assessment of environmental injustice in Korea using synthetic air quality index and multiple indicators of socioeconomic status: A crosssectional study, Journal of the Air \& Waste Management Association, 66(1), pp. 28-37.

Gottlieb, Robert (2009). Where we live, we work, play and eat: expanding the environmental justice agenda, Environmental Justice, 2(1), pp. 7-8. DOI: 10.1089/env.1009.0001

Guha, Ramachandra \& Gadgil, Mavdad (1995) Ecology and Equity: the use and abuse of Nature in Contemporary India, London, Routledge Press.

Guha Ramchandra \& Martínez Alier Joan (1997) Varieties of environmentalism, London, Essays North and South, Earthscan.

Harris, Paul \& Lang Graeme (eds.) (2015) Routledge Handbook of Environment and Society in Asia, New York, Routledge Press.

Homer-Dixon Thomas (1991) On the Threshold: Environmental Changes as Causes of Acute Conflict, International Security, 16(2), pp. 76-116.

Heijden, Van Der (2006) Environmental Movements and International political opportunity structures, Organization \& Environment, 19, pp. 28-45.

Herrero, Amaranta \& Vilella, Mariel (2017) We have a right to breathe clean air': the emerging environmental justice movement against waste incineration in cement kilns in Spain, Sustainable Sciences, 13(3), pp. 721-731. DOI: https://doi.org/10.1007/s1162 5-017-0473-x

Jackson, Ben (2017) Coal Dust and Hot Air: South Korea's Dirty Energy Habit. [Online] https://www.koreaexpose.com/coal-dust-air-south-korea-dirty-energy/ [Accessed October, 10, 2019]

Jones, Robert Emen \& Dunlap, Riley (1992). The social bases of environmental concern: have they changed over time?, Rural Sociology, 57(1), pp. 28-47.

Kc Cottell (2019) Dangjin Coal-Fired Power Plant. [Online] http://kc-cottrell.com.vn/en/ story/dangjin-coal-fired-power-plant-south-korea. [Accesed October, 20, 2019]

KEI (2009) Environmental Policy for Low-Income People in Urban Areas III. Korea Environment Institute Research Reports Volume 1, Seoul, Korea: Korea Environmental Institute.

Kim, Sun Young; O’Neill, Marie; Tae- Lee, Jong; Cho, Youngtae \& Ho Kim (2007) Air pollution, socioeconomic position, and emergency hospital visits for asthma in Seoul, Korea, International Archives of Occupational and Environmental Health, 80, pp. 701-710. DOI: doi:10.1007/s00420-007-0182-3 
Kim, Jum Wk (2008) Environmental conflicts and activism with industrialization in South Korea, CLEAN - Soil Air Water, 36(5-6), pp. 419-425.

Kim, Se-jeong (2017) Residents vow full-fledged fight against coal-fired power plants [Online] http://www.koreatimes.co.kr/www/nation/2017/05/371_230056.html [Accessed October, 15, 2019]

Koo, Dae Sum \& Kim, Il Woo (2012/10/09) Residents of disaster zone demand compensation [Online] http://english.hani.co.kr/arti/english_edition/e national/554952.html [Accessed October, $18,2019]$

$\mathrm{Ku}$, Dowan (2011) The Korean Environmental Movement: Green politics through Social Movement in Broadbent, J. et al (eds.) East Asian Social Movements. Nonprofit and Civil Society Studies (an Interntional Multidisciplinary Series), New York, Springer Publisher, pp. 205-229.

Lora-Wainwright, Ana; Zhang, Yiyun; Wu, Yunmei \& Van Rooij, Benjamin (2012) Learning to live with pollution: the making of environmental subjects in a Chinese industrialized village, China Journal, 68, pp. 106-124.

Lora-Wainwright, Ana (2017) Resigned activism: living with pollution in Rural China, Cambridge, Mass MIT Press,

Ma, Chunbo (2010) Who bears the environmental burden in China - an analysis of the distribution of industrial pollution sources?, Ecological Economics, 69(9), pp. 1869-1876.

Martínez Alier, Joan \& O`Connor, Martin (1996) Ecological and economic distribution conflicts in Constanza, R. et al Getting down to Earth. Practical Applications of Ecological Economics, Island Press, Washington, pp. 153-183.

McAdam, Doug, Tarrow, Sidney \& Tilly, Charles (2001) Dynamics of Contention, New York, Cambridge University Press.

McAdam, Doug, McCarthy, John \& Mayer, N. Zald (eds.) (2004) Comparative Perspectives on Social Movements: political opportunities, mobilizing structures and cultural framings, Cambridge, Cambridge University Press

Martínez Alier, Joan (2002) The Environmentalisms of the Poor. A study of ecological conflicts and valuation, Edward Elgar Publishing.

Martinez-Alier, Joan; Kallis, Giorgos; Veuthey, Sandra \& Walter Temper, Mariana (2010).Social metabolism, ecological distribution conflicts, and valuation languages, Ecological Economics, 70(2), pp. 153-158.

Martínez Alier, Joan; Temper, Leah; Del Bene Daniela \& Scheidel, Arnim (2016). Is there a global environmental justice movement?, Journal of Peasant Studies, 43, pp. 731-755

Mignolo, Walter (2000) Border Thinking and the Colonial Difference. In Local Histories/ Global Desings: Coloniality, Subaltern Knowledges and Border Thinking, New Jersey, Princeton University Press, pp. 49-90.

Mignolo, Walter (2000a) Diferencia colonial y razón post-occidental. In Castro-Gómez, Santiago (ed.) La reestructuración de las ciencias sociales en América Latina, Bogotá, Instituto Pensar, Pontificia Universidad Javeriana, pp. 3-28.

Mignolo, Walter (2003) Historias locales/diseños globales. Colonialidad, conocimientos subalternos y pensamiento fronterizo, Madrid, Akal.

Ministry of Environment of South Korea (2013-14) Reinforced Management of Chemical Safety [Online] http://eng.me.go.kr/eng/web/index.do?menuId=349 [Accesed November, 20, 2019]. 
Ministry of Trade, Industry \& Energy, Invest Korea. Gumi National Industrial Complex 1 (taken from Invest Korea) [Online] (http://www.investkorea.org/kr/location/zone05.do? $\underline{\text { mode }=\text { download\&zone } \mathrm{idx}=31 \& \text { name }=\text { zone } p \text { df file. }}$. [Accessed December, 18, 2019]

Motie Notice (2016, March). The 7th Basic Plan for Long Term Electricity Supply and Demand (2015-2029) [Online] http://www.kpx.or.kr/eng/downloadBbsFile.do?atchmnflNo=26448. [Accessed October, 20, 2019]

Nixon, Rob (2011) Slow Violence and the environmentalism of the poor, Cambridge, Harvard University Press.

Nihon Kankyo Kaigi (2009) The state of the Environment in Asia 2006-07, Japan Environmental Council Staff, Nihon Kankyo Kaigi, United Nations University Staff.

Ortega Santos, Antonio (2002) La Tragedia de los Cerramientos. Desarticulación de la Comunalidad en la Provincia de Granada, Alzira, Centro Francisco Tomás y Valiente/Fundación Instituto de Historia Social.

Ortega Santos, Antonio (2007) Where have all the flowers gone? Aprovechamientos forestales y desarticulación de la comunalidad en la provincia de Granada, siglos XIX-XX. In Araque Jiménez, Eduardo \& Sánchez Martínez, José Domingo (eds.) Los montes andaluces y sus aprovechamientos: experiencias históricas y propuestas de futuro, Jaén, Universidad de Jaén, pp. 59-95.

Ortega Santos, Antonio (2012) El comunal imaginado. De la Transición en los Usos de la propiedad comunal en el siglo XX, Güejar Sierra, Historia Agraria, 58, pp. 73-112.

Ortega Santos, Antonio \& Olivieri, Chiara (2016) Miradas coloniales vs. decoloniales a los conflictos y resistencias ambientales para el mundo actual. In Zarrilli, G. (ed) Por una Historia Ambiental Latinoamericana. Aportes para el estudio de la sociedad y la naturaleza en la era del Antropoceno, Buenos Aires, Ed. TESEO, pp. 55 - 95.

Park, Soo Bin $(2013 / 6 / 2)$ Alert over South Korea toxic leaks [Online] https:// www.nature.com/news/alert-over-south-korea-toxic-leaks-1.12369 [Accessed October, 20, 2019].

Pellow, David N; Weinberg, Adam \& Schnaiberg, Allan (2002) The environmental justice movement: equitable allocation of the costs and benefits of environmental management outcomes, Social Justice Research, 14(4), pp. 423-439.

Peluso, Nancy \& Watts, Michael (2001) Violent Environments, Cornell University Press Ithaca.

Power technology (2019). Dangjin Coal-Fired Power Plant [Online] https://www.powertechnology.com/projects/dangjin/. [Accessed October, 25, 2019]

Pudasainee, Deepah; Kim, Jeong-Kum \& Seo, Yon-Chil (2009). Mercury emission trend influenced by stringent air pollutants regulation for coal-fired power plants. Korea in Atmospheric Environment, 43(39). [Online] https://www.sciencedirect.com/science/article/pii/ $\underline{\mathrm{S} 1352231009004993}$. [Accessed November, 25, 2019]

Santos, Boaventura de Sousa (2010). Descolonizar el saber, reinventar el poder, Uruguay, Trilce Editorial.

Santos, Bovaentura De Sousa \& Meneses, María Paula (2014) Epistemologías del Sur (Perspectivas), Madrid, Ed. Akal.

Scheidel, Adam; Temper, Leah, Demaria, Federio \& Martinez-Alier, Joan (2018). The Global Environmental Justice Atlas (EJATLAS) Ecological distribution conflicts as forces for 
sustainability: an overview and conceptual framework, Sustainable Science, 13(3), pp. 573-584. DOI: https://doi.org/10.1007/ s1162 5-017-0519-0.

Spiric, Jovanla (2018) Ecological Distribution Conflicts and sustainability: lessons from the post-socialist European Semi-Periphery, Sustainable Science, 13(3), pp. 661-676. DOI: https:// doi.org/10.1007/ s1162 5-017-0519-0

Tarrow, Sidney (1992) Mentalities, Political cultures, and colllective action frames: constructing meanings through action. In Frontiers in Social Movement Theory, New Haven, Yale University, Press, pp. 174-202.

Temper, Leah; Walter, Mariana; Rodriguez, Kothari A; Turhan, Ethencam (2018) A perspective on radical transformations to sustainability: resistances, movements, alternatives, Sustainable Science, 13(3), pp 747-764. DOI: https://doi.org/10.1007/s1162 5-018-0543-8

Tilly, Charles (2002) Stories, Identities and political change, Rowmanand, Littlefield Lanham

Yonhap Editorial (2012/10/04) Designation of gas leak site as 'disaster zone' should be considered [Online] https://en.yna.co.kr/view/AEN20121004009500315?section=search. [Accessed October, 22, 2019]

Yonhap News (2012/10/05) State level probe into chemical leak begins [Online] https:// en.yna.co.kr/view/PYH20121005161100341?section=search. [Accessed October, 24, 2019]

Yonhap News (2012/10/06) Residents demand to relocate after gas leak [Online] https:// en.yna.co.kr/view/PYH20121006012900320?section=search. [Accessed October, 22, 2019]

Yonhap News (2013/05/27) Deaths from chemical accidents jump in 2012 [Online] https:// en.yna.co.kr/view/AEN20130527007300315?section=search. [Accessed October, 25, 2019]

Yonhap News (2013/07/05) Large firms to invest big to prevent chemical accidents [Online] https://en.yna.co.kr/view/AEN20130705002000315?section=search. [Accessed October, 22, 2019]

Yonhap News (2013/07/24) Civilian experts to assist gov't response to chemical accidents. [Online] https://en.yna.co.kr/view/AEN20130724002200315?section=search. [Accessed November, 24, 2019]

UN Environment. (2019) Environmental Health Plan 2006-2015. Republic of Korea. Ministry of Environment [Online] http://wedocs.unep.org/handle/20.500.11822/9003. [Accessed October, 24, 2019]

Wallerestein, Inmanuel (2009) El moderno sistema mundial I, la agricultura capitalista y los orígenes de la economía-mundo europea en el siglo XVI, Madrid, Siglo XXI.

Wu, Fengshi (2015) Nongovernmental Organizations and Environmental Protests: Impacts in East Asia. In Graeme, Lang \& Harris, Paul (eds.), Routledge Handbook of Environment and Society in Asia, London, Routledge Press, pp. 105-119.

Web pages:

http://globalenergyobservatory.org/geoid/2865

https://www.ewp.co.kr/eng/main/main.asp

https://www.industryabout.com/country-territories-3/2005-south-korea/fossil-fuels-energy/ 30755-dangjin-9-10-coal-power-plant

https://www.oecd-ilibrary.org/economics/oecd-economic-surveys-korea-2014_eco_surveyskor-2014-en 
http://climatepolicydatabase.org/index.php/7th_Basic_Plan_for_LongTerm_Electricity_Supply_and_Demand_2015-2029

\author{
Related photos: \\ http://www.koreatimes.co.kr/www/nation/2017/05/371 230056.html
}

PROCESO EDITORIAL • EDITORIAL PROCESS INFO

Recibido: $12 / 07 / 2019$ Aceptado: 19/02/2020

CóMo CITAR ESTE ARTÍCULO • HOW TO CITE THIS PAPER

Ortega Santos, Antonio, Herráiz Martín, Susana, Mora Roás, Enrique (2019) Far from heaven, grounded on Earth: Environmental (In)justice in Soth Korea. Revista de Paz y Conflictos, Vol.12 (2), 11-33.

\title{
SOBRE LOS AUTORES • ABOUT THE AUTHORS
}

Antonio Ortega Santos es Profesor Titular de Historia Contemporánea y Coordinador del Programa de Doctorado Internacional en Historia y Artes de la Universidad de Granada y Coordinador del Master de Estudios de Asia Oriental durante los años 2016-2018. Miembro de la Ejecutiva de la Sociedad Latinoamericana de Historia Ambiental (SOLCHA) y Coordinador de la Red Universitaria Española de Historia Ambiental. Ha desarrollado Estancias de Investigación en Universidad de Yale (EEUU), UNAM, Fundación Antonio Núñez Jiménez (La Habana) y Universidad Autónoma de Baja California Sur. Es autor de 9 Libros y mas de 70 artículos y capítulos de libros en Editoriales de ámbito Nacional e Internacional.

Enrique Mora Roás es Graduado en Estudios de Asia Oriental con mención Japón por la Universidad de Sevilla. Cursó su tercer año en la Universidad de Tokio completando el programa Global Studies in Asia. Máster en Estudios de Asia Oriental con especialización en Lengua, Literatura y Cultura Japonesas por la Universidad de Granada. Sus principales líneas de investigación son la ideología, la construcción del poder político y la lucha de los colectivos subalternos por razón de clase, género y etnia en Asia Oriental a lo largo de diferentes etapas históricas. Email. enriquemoraroas@gmail.com

Susana Herráiz Martin es Investigadora Doctoral del Programa de Doctorado en Historia y Artes de la Escuela de Humanidades, Ciencias Sociales y Jurídicas de la Universidad de Granada en la línea de Territorio, Patrimonio y Medio Ambiente con un proyecto de investigación orientado al estudio de las políticas ambientales en Corea. Egresada del Master de Estudios en Asia Oriental. 